- Editorial

\title{
Medical Student Debt: What Perspective Should We Take?
}

\author{
Kieran Walsh* \\ BMJ Learning, London, UK
}

Since medical education is expensive, healthcare professional students in many countries must take out loans to pay for their studies. The resultant levels of debt have created concerns at both the beginning and the end of undergraduate education. How should medical educators respond to these concerns? If educators are to look at medical education from the perspective of their students who are most in need, then they should think about this. Educators should think about their response when current or prospective students ask them about mitigating the costs of medical education. This may include questions about working during undergraduate studies, the costs of living in different locations, and the availability of bursaries that offer financial aid to students. Medical students should be encouraged to "think like an investor" when making decisions related to their medical education. Senior medical educators should be well placed to advise them in this regard.

Keywords: Medical Education; Cost 
Medical education is expensive. ${ }^{1)}$ As a result, in many countries, healthcare professional students, especially medical students, must take out loans to pay for their studies. Many universities in the UK charge $£ 9,000$ per year in tuition fees. In addition, there are accommodation, subsistence, and living expenses. This results in students' debts touching a five-digit figure. This large amount of debt has created concerns at both the beginning and the end of undergraduate education. First, does the probability of a large debt deter certain high school graduates from studying medicine? Second, does the reality of large debts drive healthcare graduates to high-earning specialties in order to pay off their debts more quickly?

We as educators can respond to these concerns in many ways. We can lobby for free or low-cost medical education. We can campaign for debt forgiveness. We can lobby for more outreach schemes to make medicine an attractive career for youth from diverse backgrounds. However, what will be the outcome of our efforts? At best, it may create some impact in the long term, and at worst, it may create no impact at all. This in turn raises the following questions: what small practical assistance can we offer to medical students who are worried about the cost of medical education? Should we even be concerned about this topic? Should medical educators limit their interest to curriculum design and redesign, and the lives of their students while they are in the school? I would say no. Just as we engender good learning and teaching skills in our students, we should also engender the skills that may prove equally helpful for them to achieve their degree and graduate as doctors. The following are some examples of how educators could help.

First, some medical students who are concerned about debt work part time to earn money while studying. What should be our advice to them? There are advantages and disadvantages to taking up a part-time job while at medical school. It can reduce graduate debt, provide an important life experience enabling the development of transferable skills, and provide work experience in a job that is allied to medicine or healthcare. However, time at medical school is at a premium. There is always a concern that a job could eat into study time. Most institutions advise students against working more than 15 hours per week while studying full time. It is important to discuss to what extent work can be aligned with education. Ideally, a student should be able to earn money and at the same time develop knowledge or skills related to medicine (maybe as a nursing aid or assistant librarian).

Second, costs of living differ across locations. What if a prospective student asks about the medical school he/she should attend and the cost of living in different areas? Should we incorporate this factor in our advice? It cannot be ignored. Tuition fees of the institutions and accommodation costs vary widely depending on the location. A high school graduate considering a career in medicine may be tempted by a school with lower fees in a low-cost location. Living with one's parents while studying can be a worthwhile option for some medical students. If we are serious about widening participation in medicine, then we need to think beyond the classical university experience. At present, only a tiny minority of medical students come from social class VII-the poorest social class. ${ }^{2,3)}$ Measures to address factors such as tuition fees, accommodation costs, or even living with parents could be important in increasing this number.

Third, medical students can apply for grants or bursaries offered by charitable organizations and national health or educational institutions. These grants or bursaries may offer variable levels of financial support and have different eligibility requirements. However, their ultimate aim is to offer support to those medical students who need it most. Familiarizing ourselves with these potential resources will be worthwhile.

These are just few examples of tactical opportunities that medical students can take advantage of. These examples are not comprehensive, but they can significantly help cover the costs. However, a wider strategic point is that medical students should be encouraged to "think like an investor." ${ }^{4,5}$ ) They will be investing a large amount of money in their tuition and living over a five- or six-year period. This is in addition to opportunity costs-the earnings that they would have accrued if they had not been in medical school. Balancing these opportunity costs with the outcomes they are aiming to achieve is important. This is a difficult task for an-eighteen-year-old. A student from a low-income background whose parents never attended university may have a different perspective than that of a student from a more well-off background. In this situation, mentors, outreach workers, tutors, and clinical teachers should act 'in loco parentis.' These educators can help the students put debt into perspective and realize that there are a number of ways to mitigate that debt.

There are many studies available on primary care. Youngclaus et al. ${ }^{6)}$ found that graduates with higher levels of debt who choose primary care as a career may struggle with repayments. According to Phillips et al., ${ }^{7)}$ high debt "deters graduates of public medical schools from choosing primary care, but does not appear to influence private school graduates in the same way." According to Rohlfing et al., ${ }^{8)}$ students with higher debts were "less likely to choose primary care specialties."

Should we pay special attention to the perspective of learners when we discuss perspectives in medical education? Should we put on wide-angle lenses and look through their perspective at a range of phenomena in their lives? I would argue that we should; otherwise, a new hidden curriculum may emerge where the taught curriculum focuses on basic and clinical sciences, and the hidden curriculum covers worrying about debt with no one to talk to, making wrong decisions on the basis of limited information, and not realizing that there are several opportunities to avoid or lessen medical student 
debt. ${ }^{9)}$ We should strive to prevent this hidden curriculum from emerging.

\section{CONFLICT OF INTEREST}

No potential conflict of interest relevant to this article was reported.

\section{REFERENCES}

1. Walsh K, Jaye P. Cost and value in medical education. Educ Prim Care 2013;24:391-3.

2. British Medical Association. Equality and diversity in medical schools [Internet]. London: British Medical Association; c2009 [cited 2013 Jun 18]. Available from: http://bma.org.uk/developing-your-career/becoming-a-doctor/equality-and-diversity-in-medical-schools.

3. Seyan K, Greenhalgh T, Dorling D. The standardised admission ratio for measuring widening participation in medical schools: analysis of
UK medical school admissions by ethnicity, socioeconomic status, and sex. BMJ 2004;328:1545-6.

4. Barron J, Foxwell T, Steel D. Degrees with less debt. Trowbridge: Lifetime Publishing, 2011.

5. Sandars J, Walsh K. A consumer guide to the world of e-learning. BMJ Career Focus 2005;330:96-7.

6. Youngclaus JA, Koehler PA, Kotlikoff LJ, Wiecha JM. Can medical students afford to choose primary care?: an economic analysis of physician education debt repayment. Acad Med 2013;88:16-25.

7. Phillips JP, Petterson SM, Bazemore AW, Phillips RL. A retrospective analysis of the relationship between medical student debt and primary care practice in the United States. Ann Fam Med 2014;12:542-9.

8. Rohlfing J, Navarro R, Maniya OZ, Hughes BD, Rogalsky DK. Medical student debt and major life choices other than specialty. Med Educ Online 2014;19:25603.

9. D'Eon M, Lear N, Turner M, Jones C; Canadian Association of Medical Education. Perils of the hidden curriculum revisited. Med Teach 2007; 29:295-6. 